\title{
The dimensions of the experiment in experimental Dharma: a response
}

\author{
Laurie L. Patton(D)
}

\author{
Correspondence: \\ laurielpatton@gmail.com \\ President and Professor of Religion, \\ Middlebury, USA
}

What does it mean to be experimental in the context of dharma? In so far as dharma is understood to be grounded in human experience, all dharma might be understood as experimental-focused on independent confirmation and individual sensory knowledge and experience. This perspective is true of both the Hindu and the Buddhist traditions, broadly conceived. As John Nelson also writes in the author's article for this special issue, "experiment" is an analytical concept and an observable set of behaviors, and "experimental religion" could be understood as those sets of behaviors that connect religious resources with changing contemporary trends.

But the term "experiment" is not just a helpful way to think about how Buddhists, Hindus, and Sikhs engage with change in the contexts of various Dharma Traditions in Asia and the Diaspora. As the editor of this journal symposium, and the author of "Dharma is Technology," Antoinette E. DeNapoli, also writes, experiment is an important descriptor in the field of religious studies and anthropology. The term can help scholars in to make sense of the empirical dimensions of human experience and practical acquisition of knowledge by means of such experience.

In my response to the articles gathered in this issue, I will assess both the descriptive power and analytical purchase delivered by the term "experimental" when studying the concept of dharma. It is important to note here that, while both Buddhist and Hindu traditions use the term, what is meant by it can be very differently inflected. To restate the obvious for purposes of clarity: dharma in Hinduism tends to mean "sacred duty," or "social law." Dharma in Buddhism tends to mean the teachings of the Buddha, or traditional teachings. Both usages, however, have the connotations of "what ought to be done." The Sanskrit word kartavyam-what is to be done-might be a helpful term to think of, and is often invoked, in relationship to dharma in multiple contexts both Hindu and Buddhist.

Exploring the history of an English word in the Oxford English Dictionary often helps us assess its descriptive power and analytical purchase. The authors of this special issue use the term "experiment" both as a noun and a verb, and so we explore accordingly. "Experiment's" earliest usages as a noun involved the action of trying something, putting something to a test or a proof. Relatedly, but slightly later, the word experiment connotes "A tentative procedure; a method, system of things, or course of action, adopted in uncertainty whether it will answer the purpose." And an obsolete but perhaps helpful resonance here is "an expedient or remedy to be tried." And in the definition most known to us today, experiment is understood as "an action or operation 
undertaken in order to discover something unknown, to test a hypothesis, or establish or illustrate some known truth." (http://xu8kt9sn3c.search.serialssolutions.com/?sid=ser sol\&SS_jc=JC_008566792\&title=Oxford\%20English\%20Dictionary\%20\%28Online\%29).

As a verb, an obsolete term may still have resonance given the articles in this issue. Early meanings connote, "to have experience of; to experience; to feel, suffer." And a later verbal meaning is "to ascertain or establish by trial (a fact, the existence of anything, etc.)." And finally, we have our more well-known contemporary meaning, of "making an experiment, conducting a test of a hypothesis." (Ibid.)

I belabor these different meanings because, with one important exception I will discuss below, I think they are all present in this issue. All the forms of dharma discussed here grapple with the implicitly experimental nature of religious innovation, of making a new form of dharma in hopes that it will be effective. The governments of Indonesia and Japan both create and establish new rituals and definitions as they attempt to shape a stateacceptable form of Hinduism and Buddhism. Japanese priests reconfigure Buddhist teachings to engage technology, individualism, and market economies. The Santmat religion takes on the novel idea that marginalized Hindus can still be part of a Vedic perspective. The Hindu renouncers understand technology and science as part of the "new steps" of following dharma, even as they claim it as "original" to the Hindu tradition.

Let us take some time to examine the dimensions of these implicit experimental perspectives. For these authors, experimental dharma foregrounds the role of agency in change. According John Nelson, many of the Japanese priests themselves are looking at new forms of agency that make ancient teachings of Buddhism more relevant in Japan—such as social movements and environmental activism. Their new positioning creates such an agency in "negotiating a combination of teachings and practices in modern contexts." Purushottama Bilimoria, too, emphasizes agency when he notes that second/third generation Hindus and Sikhs go on to universities, but do not necessarily or in large proportions become doctors, surgeons, academics and engineers with same earnestness as parents did. Bilimoria further suggests that such agency is a sign of "post postcolonial reversal."

However, agency is not entirely contemporary autonomy. As Antoinette E. DeNapoli notes, the Hindu sadhus are clear that their contemporary, science-and-technologyinflected lives are part of their religious perspectives. Even as lived before taking sannyas, these perspectives are part of teaching dharma and what has led them to dharma. In an ironic twist, that lifelong agency is part of a destiny that makes them friendly to dharma. So, too, in Jessica Starling's exposition, the idea of agency is central to the new rituals for the wives of Japanese priests. However, even in this idea that priest's wives freely choose their roles as a form of contemporary agency, Starling reminds us that, from premodern doctrinal standpoint, "not a truly autonomously chosen position but result of unknowable chain of connections."

Second, for these authors, experimentation involves the role of sense experience in everyday life. In that way, their understanding of experimentation calls upon earlier notions of the term, "to experience, to feel to suffer." As Nelson puts it, Buddhist-inspired activism can thus help identify and analyze actions and policies based upon Buddhist traditions that exhibit pragmatic, experimental approach towards fostering social change. As June McDaniel shows, the new Indonesian rituals for Hindus still focus on the role of the senses in understanding Brahman. So, too, do the teachings of the more 
marginal Santmats which Veena Howard discusses. As Howard writes, this movement makes the esoteric practices more meaningful and relevant to everyday lives of the tribal and rural people of Bihar and Nepal. Local religious vernaculars give expression to engagement with "lived devotional traditions", and foster various forms of hybridity and syncretism. Bilimoria writes of the minimalism in some Hindu and Sikh approaches to diaspora, which turns to everyday life and its power. In their reconfiguration of diaspora identity in the new horizon, they "turn not to local temples but their own mandalas and bhajana groups." In this sense they are, as Bilimoria puts it, "desiporic"-following an inherent logic of tradition in a "new" home that is still older than their parents' "new" home.

The role of the senses is perhaps most engaged by Gregory D. Alles, in his discussion of image schemata in the Rathva rituals and thresholds of transition in Chhotaudepur District, Gujarat. Here, deities and transitions are implied by the "borders" constructed by Rathvas, and must be apprehended by the senses even though they are not fully present to them. These are temporary, always-moving sites of ritual practice where borders are imaginatively constructed. The Rathva locate borders at natural or artificial borders, constructing them in order to locate a place for devs and ancestors. They construct these thresholds in order to breach imaginatively-thus the role of both the senses and imagination is central.

Relatedly, the role of the vernacular is prominent as a theme throughout. For most of these authors, innovation in dharma allows for authentic responses in vernacular cultures. DeNapoli writes of the "vernacular" asceticism that the sadhus exhibit, where their use of technology creates their own renunciant forms of worship. As DeNapoli writes, changes that occur in vernacular asceticism-crucial and yet quotidian-do not break away from other dharma traditions, nor do they gerrymander its relevance (p.xx). And the vernacular plays a large theoretical role in Howard's discussion of the Santmats. Following anthropologist of religion Leonard Primiano (1995), Howard writes that the Santmat movement enacts creative integration of vernacular traditions through bricolage. These are what this author calls experimental dharmas in vernacular Sant traditions. The characteristics of this hybrid religiosity are such that "ambiguity, power, and creativity shape interpretation of religious experience and tradition," thus "vernacular Vedic dharma."

So far, then, our authors understand experimentation as a willingness to try something new, a focus on agency, a grounding in sense experience and an appeal to everyday practice, and being situated in and relevant to vernacular sensibilities. All of the dharmas in these articles, to some degree or another, share these characteristics. And for the most part, (with one key exception to be discussed below), these forms of dharma fall into the historical resonances and current meanings of the word "experiment."

The articles differ, however, in the ways in which these dharmas are situated in society. Some dharmic innovations depend on the center, and other experiments depend on the periphery. Let us turn to the most surprising element of several of our authors-the experimentation from the center. We learn that in many contexts, experimentation in dharma is not the result of the rebellious individual. The roguish sense of experimentation-the individual or group thinking freely against the bureaucratic grain-is not the story of many of these case studies. There is a deep bureaucratic sensibility which inspires the "center" to create the rituals of temple wife in Jodo Shinshu. Indeed, Starling argues against a false dichotomy concerning religious traditions as stolid conservative and 
creative dynamic negotiations. The "experiment" in this scholar's case is very much originated and perpetuated by the central authors.

So, too, McDaniel notes that Indonesian Hinduism is an entirely new form of Hinduism developed by scholars, psychologists and priests-leaders mostly at the center of society. Leading intellectuals and thinkers also enact changes in ritual arts and theology. They are the creators of new rituals such as Sudhia Wadani (the call to prayer), the idea of a monotheistic god concerned with sin and salvation, and prophets and revelations. This is a result, McDaniel argues, of government policy declaring only monotheistic religions to be legitimate, and a response to the government's call to fulfill requirements for a sacred text (agamas) a prophet (rishis) and a universal ethical code. These central figures are the ones who identify mantras on the unity of Brahman as divine ruler, and codify the five pillars of belief (brahman, atman, karma, moksa, and reincarnation) and the five pillars of practice (yadnya).

And yet other authors point to experiment from the periphery, and innovative activity which in fact depends on the periphery. As Howard notes, Maharshi Mehi confronted scholars' presuppositions of rigid textual boundaries and identity formations. He made connections between Santmat and Hindu dharma. He and other Santmat leaders select philosophical writings and myths of Hindu dharma-to show the link between creative and orthodox thinkers. They do so to create a common religious language to communicate esoterica, and to "address the contemporary rise of extremism by showing how Vedic dharma encourages adherence to harmonizing inner path." All of this, in Howard's assessment, cannot be done from an orthodox "center," but by remaining on the periphery of dogmatic Hinduism.

So, too, Bilimoria writes that ambivalence of diaspora religiosity means that it is both experimental and permanently marginal. As Bilimoria puts it, diaspora, or "desipora" communities wanted to leave their countries often for reasons powered by global ideologies, but at the same time, globalization then becomes "not a positive but a source of worry re inclusions, jobs, and deeper marginalization."

Finally, these articles also, both explicitly and implicitly, address the "scientific" element of experimentation. The rhetoric of science is most deeply present in DeNapoli's perspective on the "techno-science" of the sadhus. As DeNapoli writes, most of her collaborators understand techno-science to be as ancient as sannyas-for them, "sannyas bridges inner science of dharma with outer science of technology." And, in the avatar Kalki, they even create a metaphor for the evolving relationship between humans and technologies. There are also other, less explicit ways in which science is present in these expositions: the environmentalism of Buddhist Japan that Nelson writes about depends upon scientific assessments of environmental damage and global warming. The power of trial and error is present in the scientific world views of the diaspora thinkers that Bilimoria writes about, most prominently in the Silicon Valley professionalism of the first and second generations. And, as Alles points out, the ways in which Rathvas assume inferential thinking, based on unconscious, sense-experience, image-schemata assumes a certain kind of "trial and error" conversation with both the physical world and the deities.

In the end, do we have the kind of rigorous analytical category, even if provisional, that can show new dimensions in the history of dharma? Is this phrase more helpful than, say, if the present special issue focused on "dharma, adaptation, and social change?" The response is: just barely. There is much of the analysis of these articles 
that falls under that larger description of adaptation and social change, and only a little that could fall outside it. The little that could fall outside it might be the kernels of the next steps of scholarly inquiry into experimental dharma.

What these pieces do not discuss, however, is the explicitly self-reflective aspects of such experimental work. A thorough understanding of the term "experimentation" involves self-awareness, a cognizance of the provisional nature of the undertaking until the experiment is over, the hypothesis has been proven, or the error exposed. How do these studies deal with that cognizance of process, or meta-theoretical perspective? On the one hand, we could view most of the case studies discussed in this issue as a kind of high pragmatism - the kind described as early as Bronislaw Malinowski in his essay on Magic Science and Religion. In that classic, Malinowski noted that Trobriand Islanders in their responses to difficulties are highly pragmatic, and move to spells and chants only when their experience of trial and error fails.

But in these cases we do not have a statement of a dharmic actor who declares, "I am conducting an experiment in dharma to see if this works." Nor do we have what Deborah Mayo (1996) argues is an explicit philosophy of experiment, based on learning from error and models to account for that error. We have in these articles fascinating approaches to dharma grounded in the rhetoric of experience, but that is distinct from an explicit embrace of procedure, error, and re-trial.

In fact, one could arguably interpret these innovative dharmas as attempts to be more certain, not attempts to question. In the spirit of that hypothesis, let me ask some provocative questions: Are the dharmic teachings with new technologies conducted by the sadhus in North India explicitly provisional and hypothetical? Or are they attempts to spread dharma through new modalities which will prove its truth more effectively? The Rathva are engaging in image schemata in their rituals and their constructed thresholds, and intriguingly, without strict permanent boundaries outlining the sacred. But do the Rathva state the provisional nature of their work? Maharshi Mehi makes clear his decision to remain marginal but connect Santmat tradition to Vedic tradition. But is he explicit about this as an experiment to include Bihari and tribal people within the mainstream of Hinduism? Are the officials at the "center" of Japanese Buddhism looking at these new rituals for temple wives as "trials," or are they, in fact, bureaucratic moves whose confusing origins will be clarified over time? Are the Japanese Buddhist priests, newly aware of their positionality, engaged in a "what if" kind of thinking, or, in fact, deeply committed to proving the relevance of their traditions? The Indonesian government does not seem to be experimental in its dicta that all religions should be monotheistic, nor do the responding psychologists, priests and teachers seem to be responding in the spirit of "trying things out." Are Author Bilimoria's diaspora populations in both Australia and North America explicit about "trying" new forms of religiosity that the previous generation did not? Or are they simply stating their difference?

We do not know the answer to these questions in any great detail from the articles published here. However, all of the studies could be fruitfully extended to answer them. I certainly hope that, like John Lucy's (1993) work on "metalinguistic" understandings of the communities he has worked with, there could be a next step on what Thomas Kasulis has called the "metapragmatic" understanding of experimental dharma. How self-reflective are the teachers and shapers of these dharmas about their hypothetical, 
provisional nature? How explicit are they about the idea of a "test" to be proven or disproven as effective?

Of course, even such self-explicitly hypothetical tests are bound up with ideology, and in this case, the ideology of dharma. Gandhi's famous Autobiography: The Story of My Experiments with Truth compellingly demonstrates that mixture. However, if such selfreflexivity could be teased out and more deeply analyzed in the study of these dharmas, one would be taking into account the full dimensions of the word "experimental". Then, in my view, the idea of the experimental would be a truly compelling analytical category, and move beyond a straightforward focus on adaptation and change.

Competing interests

The author declare that he/she has no competing interests.

\section{Publisher's Note}

Springer Nature remains neutral with regard to jurisdictional claims in published maps and institutional affiliations.

Received: 2 February 2017 Accepted: 21 July 2017

Published online: 08 September 2017

\section{References}

Lucy, J. 1993. Reflexive language: Reported speech and Metapragmatics. Cambridge: Cambridge University Press.

Mayo, D.1996. Error and the growth of experimental knowledge. Chicago: University of Chicago Press.

Primiano, LN. 1995. "Vernacular Religion and the Search for Method in Religious Folklife". Western Folklore 54(1):37-56.

\section{Further reading}

Experiment. 2016. Oxford English dictionary online: Oxford University Press (www.oed.com).

Gandhi, Mohandas K. An autobiography: The story of my experiments with truth. Translated by Mahadev Desai. Ahmedabad: Navajivan Publishing House. 2012.

Kasulis, T.1992. Philosophy as Metapraxis in Discourse and Practice, Frank Reynolds and David Tracy, 169-195. Albany: State University of New York Press.

Malinowski, B.1948. Magic, science, and religion and other essays. Glencoe, Illinois: The Free Press.

Primiano, LN. 2012. Afterword: Manifestations of the religious vernacular: Ambiguity, power, and creativity, in Vernacular Religion: Expressions of Belief, Marion Bowman and Ulo Valk, 382-394. Sheffield: Equinox Publishing.

\section{Submit your manuscript to a SpringerOpen ${ }^{\circ}$ journal and benefit from:}

- Convenient online submission

Rigorous peer review

- Open access: articles freely available online

- High visibility within the field

- Retaining the copyright to your article

Submit your next manuscript at $>$ springeropen.com 